Allison Davis, John Dollard. - Washington: American Council on Education, 1940.XXVIII+299 p. 6. Dumont J. C. Counting immigrants and expatriates in OECD countries: a new perspective [Electronic resource]/ Jean-Christophe Dumont, and Georges Lemaître; OECD, Directorate for Employment Labour and Social Affairs. - [Paris] : OECD, [2005]. - Access mode : http://www.oecd.org/migration/mig/ 33868740.pdf - ([OECD Social Employment and Migration Working Papers, N. 25]). 7. Emigration of Scientists from the United Kingdom : Report of a Committee Appointed by the Council of the Royal Society. - London : Royal Society, 1963. - 32 p.

8. Green Paper: The European Research Area: New Perspectives [Electronic resource]/ Commission of the European Communities. - Brussels, 2007. - 23 p. - Mode of access : http://ec.europa.eu/research/era/ pdf/era_gp_final_en.pdf 9. Knight J. Crossborder Education: An Analytical Framework for Program and Provider Mobility / Jane Knight// Higher Education: Handbook of Theory and Research. Volume XXI / Edited by John C. Smart. - Dordrecht : Springer, 2006. - P. 345-395. 10. Knight J. Higher Education Crossing Borders / J. Knight // International Encyclopedia of Education. Third Edition / Editors-in-Chief Penelope Peterson, Eva Baker, Barry McGaw. - Oxford : Elsevier - Academic Press, 2010. - Volume 4. - P. 507-513. 11. Ko E. The Washington Accord on Engineering Curriculum / E. Ko // International Encyclopedia of Education. Third Edition/ Editors-in-Chief Penelope Peterson, Eva Baker, Barry McGaw.- Oxford: Elsevier - Academic Press, 2010. - Volume 4. - P. 209-215. 12. Obi S. O. Related Services for Children with Special Needs / S. O. Obi // International Encyclopedia of Education. Third Edition / Editors-in-Chief Penelope Peterson, Eva Baker, Barry McGaw. - Oxford : Elsevier - Academic Press, 2010. - Volume 2. - P. 834-839. 13. Proceedings of the International Congress on Technology and Blindness : Volume III: Panel III, Sound recording and reproduction. Panel IV, Adapted and special purpose devices, 2d ed. / Edited by Leslie L. Clark. - New York : American Foundation for the Blind, 1963. - 384 p. 14. Wende M. van der. Internationalization of Higher Education / M. van der Wende // International Encyclopedia of Education. Third Edition / Editorsin-Chief Penelope Peterson, Eva Baker, Barry McGaw. - Oxford : Elsevier - Academic Press, 2010. - Volume 4. - Р. 540-545. 15. Велика Хартія Університетів [Електронний ресурс]. Болонья, 18 вересня 1988. - 2 с. - Режим доступу : http:/www.magna-charta.org/resources/ files/the-magna-charta/ukrainian 16. Стрюк М. I. Витоки мобільного навчання у країнах Європейського Союзу / Микола Стрюк // Педагогіка вищої та середньої школи : [зб. наук. праць] / ДВНЗ «Криворізький національний університет».- Кривий Ріг, 2013. Випуск 38. - С. 350-355.

УДК 37:004.588

Анна Томіліна

\title{
МОЖЛИВОСТІ РОЗРОБОК ЕЛЕКТРОННИХ ОСВІТНІХ РЕСУРСІВ НА БАЗІ ЕЛЕКТРОННОЇ ПЛАТФОРМИ МООDLЕ ПІД ЧАС НАВЧАННЯ СТУДЕНТІВ IHОЗЕМНОÏ МОВИ
}

Томіліна А. О. Можливості розробок електронних освітніх ресурсів на базі електронної платформи Moodle під час навчання студентів іноземної мови.

У статті розглядаються можливості створення електронних освітніх ресурсів на базі електронної платформи Moodle для студентів-філологів, що відповідають вимогам законодавчих нормативів України. Автор наводить приклади 3 власного досвіду створення електронних навчальних курсів у межах навчально-освітнього порталу Криворізького педагогічного інституту ДВНЗ «Криворізький національний університет». 
Ключові слова: електронні освітні ресурси, електронний навчальний курс, електронна платформа Moodle, іноземна мова.

Томилина А. А. Возможности разработок электронных образовательных ресурсов на базе электронной платформы Moodle при обучении студентов иностранному языку.

В статье рассматриваются возможности разработок электронных образовательных ресурсов на базе электронной платформы Moodle для студентов-филологов, которые соответствуют законодательным нормативам Украины. Автор приводит примеры из собственного опыта создания электронных образовательных курсов, размещенных на учебно-образовательном портале Криворожского педагогического института ГВУЗ «Криворожский национальный университет».

Ключевые слова: электронные образовательные ресурсы, электронный учебный курс, электронная платформа Moodle, иностранный язык.

Tomilina A. A. Opportunities of educational e-resources development based on Moodle for students learning foreign languages.

The opportunities of e-learning Moodle which are corresponded to the Ukrainian educational standards are distinguished in the article. The author describes her own practical experience of educational e-courses development for language students on the web-portal of Kryvyi Ryh State pedagogical Institute affiliated with Kryvyi Ryh National University.

Key words: educational e-resource, educational e-course, e-learning Moodle, foreign language.

На сьогодні неможливо уявити сучасне навчальне середовище без використання інформаційних технологій. Інформатизація освіти відбувається швидкими темпами, уже досліджено різні аспекти як у теоретичному плані, так і у практичному, але про повноту дослідження цього процесу не можна говорити, оскільки технічний прогрес $\epsilon$ швидкоплинним та безкінечним, що індукує своєчасні оновлення, інновації, нововведення в освітньому середовищі. Саме це сприяє нашій зацікавленості у використанні інформаційних технологій під час викладання іноземної мови у вищій школі.

Одним із видів сучасних інформаційних технологій є електронна платформа Moodle, на базі якої розробляють електронні навчальні курси. Її відносять до вільного програмного забезпечення навчальної системи й характеризують високим технологічним та методичним рівнем, а також вона має значний педагогічний потенціал [5; 6]. Переваги та можливості впровадження електронної платформи Moodle підтверджуються методичними доробками та практичним досвідом педагогів А. Андреєва, А. Анісімова, А. Бєлозубова, А. Гильмутдінової, К. Колос, Т. Крамаренко, В. Кухаренко, Е. Смирнової-Трибульської, В. Франчука та ін.

Метою статті є аналіз можливостей розроблення електронних освітніх ресурсів на базі Moodle під час навчання студентів іноземної мови, що відповідають законодавчим нормативним вимогам, таким, як Закон України «Про Концепцію Національної програми інформатизації» від 04 лютого 1998 р., Накази МОН України «Про затвердження Положення про електронні освітні ресурси» від 01 жовтня 2012 р. та «Про затвердження положення про дистанційне навчання» від 25 квітня 2013 р.

Електронні освітні ресурси $€$ частиною сучасного навчального забезпечення навчального процесу з певним навчально-методичним призначенням та використовуються в навчальній діяльності учнів чи студентів в аудиторній, самостійній, індивідуальній чи 
дистанційній формах навчання [0; 0]. Під електронними освітніми ресурсами ми розуміємо «навчальні, наукові, інформаційні, довідкові матеріали та засоби, розроблені в електронній формі та представлені на носіях будь-якого типу або розміщені в комп’ютерних мережах, які відтворюються за допомогою електронних цифрових технічних засобів і необхідні для ефективної організації навчально-виховного процесу у частині, що стосується його наповнення якісними навчально-методичними матеріалами. Отже, відповідно до наведеного визначення маємо право розглянути електронну платформу Moodle як базу для розроблення різноманітного спектру електронних освітніх ресурсів.

Нами були розроблені електронні навчальні курси з практичного курсу англійської мови (друга мова) для студентів різних курсів в електронному середовищі Moodle в межах навчально-освітнього порталу Криворізького педагогічного інституту ДВНЗ «Криворізький національний університет» [2]. Виходячи 3 досвіду створення курсів та практики їх використання в навчальному процесі, проаналізуємо можливості розроблення електронних освітніх ресурсів на базі електронної платформи Moodle під час навчання студентів іноземної мови.

У розроблених нами електронних курсах були використані такі різновиди електронних освітніх ресурсів, як електронні аналоги друкованих видань, електронні довідники, словники, енциклопедії, електронні підручники, збірники завдань, електронні лекції, електронні дидактичні демонстраційні матеріали, аудіокниги, навчальні відеофільми, презентації, електронні тематичні зображення та відповідні добірки фотокарток, рисунків тощо, комп’ютерні тести, електронні тренажери тощо. що регламентовані «Положенням про електронні освітні ресурси» [4]. Розглянемо їх більш детально.

У кожному курсі розміщуються електронні аналоги друкованих видань чи на початку курсу, чи відповідно до кожного тематичного модулю чи заняття. Часто попитом користуються електронні довідники з граматики та фонетики англійської мови, що за планом курсу підкріплюються добіркою практичних завдань, аудіосупроводом тощо. Електронні тлумачні словники, словники синонімів, фразеологічні словники представлені у вигляді переліку гіперпосилань на вікі-сторінки в межах курсу. На базі такого інформаційного потоку студент має можливість працювати з глосарієм (рис. 1), що складається спільно викладачем та студентом у структурі курсу. Записи глосарію можуть бути взаємопов'язані, тобто студент бачить лексичні одиниці чи терміни, котрі мають більш докладне тлумачення у глосарії, з виокремленням у вигляді заливки, а при наведенні на них - підкреслювання та знак питання.

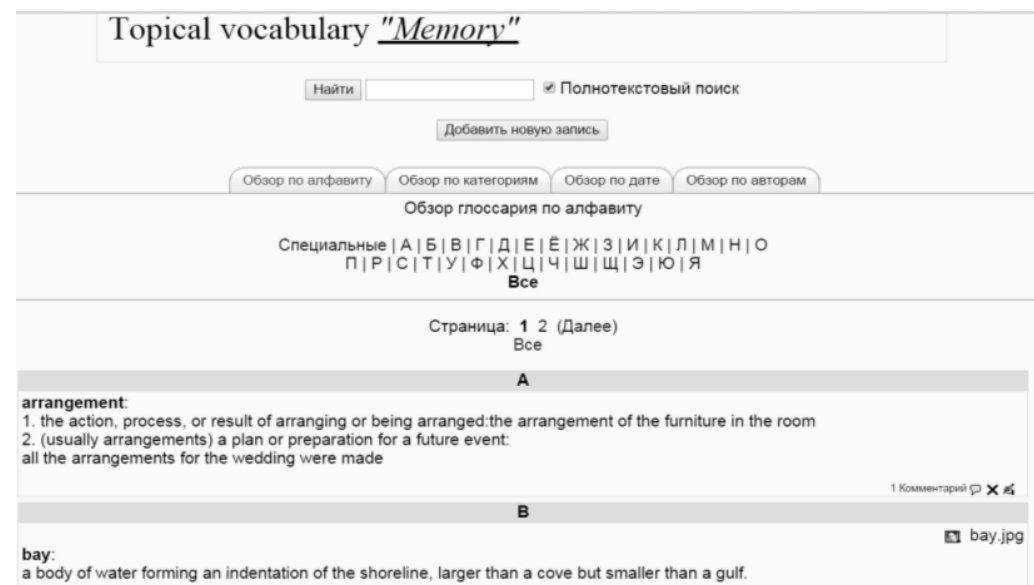

Рис. 1. Фрагмент глосарію електронного навчального курсу з англійської мови 
Дидактичні демонстраційні матеріали представлені у вигляді електронних версій таблиць, постерів, схем, презентацій, асоціативних карток. Такого типу матеріали були представлені як у теоретичному блоці, під час подачі нового матеріалу, так і в практичній частині, у складі завдань - коли таблицю необхідно доповнити, розширити дібраними зразками, за схемою навести певну кількість власних прикладів, до постерів додати відповідні репліки, картинки, заповнити асоціативні картки найбільш оригінальним чином.

Стосовно презентацій, то спектр їх використання в електронній платформі Moodle достатньо широкий та різноманітний. Наприклад, у практичному курсі англійської мови читання як вид мовленнєвої діяльності перевірявся за допомогою тематичної презентації, яку студенти переглядали та читали кілька разів, а після ознайомлення с презентаційним матеріалом студентам було необхідно виконати завдання: дати відповідь на питання, обрати правильний варіант твердження, встановити послідовність подій, про які йшла мова під час презентації.

Під час вивчення іноземної мови обов'язковим видом діяльності $\epsilon$ робота 3 аудіокнигою. Іноді поставала проблема великого розміру аудіофайлів, оскільки електронна платформа Moodle встановлює обмеження (максимум 32 Мбайти). У цих випадках доводилось розміщувати матеріал або частинами, або за межами курсу, з посиланнями на це джерело. Аналогічна справа і з відеофільмами.

Електронні тематичні зображення, добірки фотокарток, рисунків, викликають особливу зацікавленість студентів. Електронна платформа Moodle дозволяє представити їх на вікі-сторінках, у вигляді презентацій, а іноді вони є частиною тестових завдань.

Електронна платформа Moodle має великі можливості щодо впровадження цілісної системи контролю й оцінювання знань та вмінь студентів. До того ж, організація контролю й оцінювання знань та вмінь за допомогою системи Moodle має свої переваги, такі як легкість організації, різноманітність варіацій, швидкість, доступність, об’єктивність, прозорість, своєчасне програмне забезпечення, відповідність сучасним темпам інформаційного потоку тощо. Одним 3 варіантів організації контрольних дій $є$ використання елементів курсу Hot Potatoes Quiz. За допомогою цієї програми-редактора інтерактивних завдань, можливо розробити тести різної складності і різних варіацій: на множинний вибір, заповнення пропусків, пошук відповідностей, складання кросвордів (рис. 2, 3). Також мається нагода складати тести безпосередньо у самій системі електронного курсу. Задля цього формується перелік питань 3 можливістю імпортування їх з власної бази комп’ютера чи створюються умови, коли їх необхідно скласти у самій системі курсу. Ураховується, що питання до тестів можуть мати певні варіації: на множинний вибір 3 одним чи кількома правильними відповідями, питання бінарного вибору, пошук відповідностей, есе, обчислювальна відповідь, стисла відповідь тощо. До переваг відносять і те, що тести, складені у Moodle, мають певні варіативні параметри, наприклад, кількість спроб виконання, використання додаткового матеріалу, часовий ліміт тощо [5]. 


\section{Read the rules below then watch and match the rules to the places.}

Matching exercise

$1: 25$

\begin{tabular}{|l|l|}
\hline & Match the items on the right to the items on the left. \\
\hline \hline & \\
\hline London, UK \\
\hline Switzerland \\
\hline Pennsylvania, US \\
\hline Finland & If you cannot read, you must stay single. \\
\hline
\end{tabular}

Рис. 2. Зразок тесту на пошук відповідностей у Hot Potatoes Quiz

Fill in the blanks with for or since.

Gap-fill exercise

Fill in all the gaps, then press "Check" to check your answers. Use the "Hint" button to get a free letter if an answer is giving you trouble. You can also click on the "[?]" button to get a clue. Note that you will lose points if you ask for hints or clues!

Tom and Mary have been building a house $\quad$ two years. they have been dreaming of finishing it $\square$
having problems $\quad$ a few months because of the weather. In fact, it has been raining and snowing $\square$
able to put the roof on yet. This weekend they are trying to put in the windows. They have only been working
they've been doing it $\quad$ hours because it is very difficult. They have been saving up $\quad$ a long time but they haven't been able to hire

Рис. 3. Зразок тесту на заповнення пропусків у Hot Potatoes Quiz

Отже, система Moodle має різні структурні варіації використання, легко може бути адаптована до використання студентами філологічних спеціальностей у різних напрямках, $\epsilon$ безмежною базою для складання різноманітних електронних освітніх ресурсів, що регламентуються законодавчими нормативами [1; 3; 4]. Цей програмний засіб є доступним та зручним у використанні, а користувач, як викладач, так і студент, 3 мінімальними комп’ютерними знаннями може зосередитись на досягненні головної навчальної мети, а не на оволодінні технічними можливостями обраної інформаційної технології.

\section{Література}

1. Закон України «Про Концепцію Національної програми інформатизації» від 04 1998 р. $\quad$ лo 74/98-BР [Електроннй $\quad$ ресурс]. - $\quad$ Режим доступу: 
http://zakon4.rada.gov.ua/laws/show/75/98-вр. - Назва 3 екрану. 2. Криворізький державний педагогічний університет: Moodle [Електронний ресурс]. - Режим доступу: http://kdpu.edu.ua/Moodle/. - Назва 3 екрану. 3. Наказ МОН України «Про затвердження Положення про дистанційне навчання» від 25 квітня 2013 р. № 466 [Електронний ресурс]. Режим доступу : http://zakon1.rada.gov.ua/laws/show/ z0703-13. - Назва з екрану. 4. Наказ МОН України «Про затвердження Положення про електронні освітні ресурси» від 01 жовтня 2012 р. № 1060 [Електронний ресурс]. - Режим доступу: http://zakon4.rada.gov.ua/laws/show/z1695-12. Назва 3 екрану. 5. Томіліна А. О. Організація контрольно-оцінювальних дій із залученням системи Moodle для студентів гуманітарних спеціальностей / А. О. Томіліна // Теорія й методика електронного навчання. - Кривий Ріг : НМетАУ, 2012. - Вип. 3. - С. 293-298. 6. Томіліна А. О. Освітній потенціал інформаційних технологій в освітньому просторі / А. О. Томіліна // Інноваційні інформаційно-комунікаційні технології навчання математики, фізики, інформатики у середніх та вищих навчальних закладах: всеукр. наук.-метод. конф. молодих науковців, 17-18 лют. 2011 р.: [тези доп.]. - Кривий Ріг : Криворіз. держ. пед. ун-т, 2011. - Вип. 1. - С. 392-395.

УДК 65.011.46

Галина Уткіна

\section{ІНТЕЛЕКТУАЛЬНА АКТИВНІСТЬ ЯК ОСНОВА ІННОВАЦІЙНОЇ АКТИВНОСТІ}

Уткіна Г. А. Інтелектуальна активність як основа інноваційної активності.

У статті обгрунтовано зв’язок між людським фактором та виробничим фактором управління знаннями, тобто між інтелектуальною активністю та інноваційною. Визначено три впорядковані компоненти навчального процесу та їх взаємодію: джерело знань; джерело поглинання знань (студент); практичне відтворення знань. Обгрунтовано синергетичне походження знань організації.

Ключові слова: інтелектуальна активність, інновація, інноваційна активність, синергетика, знаннєва економіка.

Уткіна Г. А. Интеллектуальная активность как основа инновационной активности.

В статье обосновывается связь между человеческим фактором и производственным фактором управления знаниями, то есть между интеллектуальной активностью и инновационной активностью. В статье определены три упорядоченных компонента учебного процесса и их взаимодействие: источник знаний; источник поглощения знаний (студент); практическое воспроизведение знаний. Обосновано синергетическое происхождение знаний организации.

Ключевые слова: интеллектуальная активность, инновация, инновационная активность, синергетика, экономика знаний.

Utkina G. A. Intellectual activity as a basis of innovative activity.

In the article the relationship between the human factor and production factor knowledge management, or between intellectual activity and innovation activity. The article defines three of the ordered components of the educational process and their interactions: power knowledge; power absorption of knowledge (student); playing practical knowledge. The origin of knowledge is knowledge synergistic organization. 